elements present in petroleum, the rate of evaporation of solvents from petrol soap gels and the products formed in the pre-flame combustion of fuels in the pressure-ignition engine. The School of Malting and Brewing and the Department of Industrial Fermentation were concerned mainly with the nutritional requirements of fermentation micro-organisms and the action of the amylases. The Department of Physical and Theoretical Metallurgy extended its work on the theory of the constitution of alloys and of the deformation of metals and alloys. The electrical properties of cold-worked iron during strain-ageing were examined, and the X-Ray Laboratory extended work on a technique for studying the structure of cold-worked metals and of martensite. The Department of Industrial Metallurgy inaugurated a programme of work on the non-homogeneous deformation of metals during rolling; and the welding of aluminium alloys, the nature and effect of hydrogen absorption on the properties of spring steels, and nucleation and its effect on the cast structure of alloys were also studied. Work in the Department of Mining covered the chemical constitution of coal, low-temperature atmospheric oxidation of coal, factors influencing the properties of suspensions of solids in fluids and froth flotation of chromite.

In the Faculty of Medicine, the research activities of the Department of Anatomy were concerned with the hormonal control of reproduction, experimental embryology, the inter-relation of hormonal and neural factors in physical and behavioural men. struation, studies of growth and body proportions, and analysis of cranial and dental characters of monkeys and apes. The Department of Physiology studied the factors concerned in the maximal rate of secretion of $p$-aminohippuric acid by the kidney, visual contrast, folic acid deficiency, the role of progesterone in the mechanisms of pelvic relaxation in the mouse, metabolism of sulphonamides and the constitution of blood-group substances. Numerous investigations in the Department of Bacteriology included the cytology of bacteria, chemotherapy of tuberculosis and actinobacillosis of cattle. The Department of Pharmacology and Therapeutics was engaged in research on the main factors which determine the rate and extent of lipolysis, emulsion systems for intravenous use, lipoprotein structure and the central nervous system, and devised a new method for testing substances with anthelmintic activity, using the liver fluke.

\section{NEW ZEALAND FOREST SERVICE ANNUAL REPORT FOR 1948-49}

$\mathrm{U}$ NDER the heading "Forest Policy" in the annual report for the year ending March 1949 of the director of forestry of the New Zealand State Forest Service*, it is announced that the decision has been taken by the Government of New Zealand, after a quarter of a century of planning and research work, to establish a saw mill and a pulp and paper mill at Murupara, on the Rangitaiki River in the Rotorua Forest Conservancy-the first of its type in the Dominion. It is stated that only by the establishment of such a combination of saw mill and pulp and paper plant can exploitation of the enormous Kaingaroa

*New Zealand State Forest Service. Annual Report of the Director of Forestry for the Year ended 31st March, 1949. Pp. 86. (Wellington : Government Printer, 1949.) 18. $9 d$.
State Forest, representing an expenditure of several million pounds, be justified. "It must be reslized," says the director, "that as a saw-log development alone, the Kaingaroa State Forest could not very well be poorer, largely due to the trees having been planted too widely apart and left without any sylvicultural treatment in the interim." Therefore, the only way in which large saw-log production could be justified was by having an associated pulp and paper plant to absorb both the small-diameter and the rough knotty logs which cannot be converted into sawn timber at a profit.

References have been made in Nature during the past twenty years to the great conifer-planting schemes which were commenced during the closing years of the past century. The planting of conifers, of which Pinus insignis was the first chosen, was commenced by the Forest Department and afterwards taken up as a commercial proposition by private com. panies, the latter confining themselves almost entirely to the latter. Owing to the risks from pests and later the necessity of knowing the quality of the material being produced by this enormous area of artificially grown exotic conifers, research work was undertaken. "By 1928," says the report, "it had been proved, through the extensive tests both on the experimental scale at the famous Madison Forest Products Labora. tory and on a commercial scale at the mills of the Consolidated Pulp and Paper Co. at Wisconsin Rapids, Wisconsin, that insignis pine and other exotic softwoods could be used for newsprint, kraft and other papers. Kaingaroa State Forest was extended to provide an ample supply of pulp-wood as well as of saw-logs, etc., and ever increasing proportions of species other than insignis pine were used for this purpose."

This State forest policy was thus in strong contrast to that of the forest companies, which concentrated largely on the planting of the insignis for pulp and paper production alone. The State Forest Service had taken as its model the Scandinavian policy, which had, of course, arisen from having at the start large areas of virgin forest as a basis to establish the utilization and exploitation policy, namely, that an economic pulp and paper industry is only practicable as a supplementary activity to the utilization of saw logs "which probably for all time will remain the most important and basic product of the forest". To this latter statement there are, of course, considerable reservations in other parts of the world.

The New Zealand State Forest Service owes its present position in this matter to the late Mr. William Adamson, the technical director of Walmsleys, Ltd., Bury, England, who visited the Dominion in 1925. After examining the existing coniferous areas, transport problems and so forth, he made certain recommendations, the most important of which was that no pulp and paper plant should be established until a unit of economic size, as judged by world standards, could be justified both by continuity of wood sup. plies and adequacy of demand. Small plants cannot be developed on an economic basis. Not only has Mr. Adamson been responsible for the supply of paper machines to many parts of the world, but he has also been associated with the designing and building of some of the most famous pulp and paper plants in the world, including the enormous Conerbrook operation of Bowaters, Ltd., in Newfoundland. His greatest monument will rest upon the work he did for New Zealand, upon which this conception of a forest policy is based. 